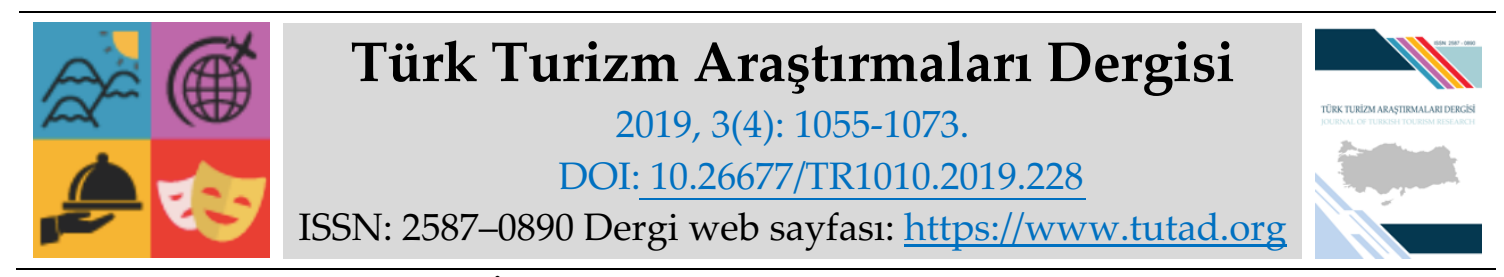

ARAŞTIRMA MAKALESI

\title{
Destinasyon Yönetiminde Toplum Temelli Turizm: Burdur ve Isparta Yöresinde Bir Araştırma*
}

Öğr. Gör. Hatice SARI GÖK, Isparta Uygulamalı Bilimler Üniversitesi, Yalvaç Meslek Yüksekokulu, Isparta, e-posta: haticesarigok@sdu.edu.tr ORCID: https://orcid.org/0000-0003-0949-2593

Doç. Dr. Şafak ÜNÜVAR Selçuk Üniversitesi, Turizm Fakültesi, Konya, e-posta: safakunuvar@gmail.com

ORCID: https://orcid.org/0000-0001-9177-8704

\section{Öz}

Alternatif turizm modellerinden biri olan toplum temelli turizm, toplum üzerine odaklanan, yerel halkın turizm faaliyetlerinden daha fazla fayda sağlamasını amaçlayan ve yerel toplumların kontrolü elinde bulundurmasını destekleyen stratejilerden biridir. Toplum temelli turizm modelinde, bölgedeki turizm plan ve yönetimine yerel halkın katılımı, aşağıdan yukarı planlama, yerel girişimciliğin desteklenmesi ve bölgedeki turizm faaliyetlerinin sürdürülebilir bir yaklaşımla değerlendirilmesi son derece önemlidir. Son yıllarda Burdur ve Isparta yöresine olan turizm talebindeki artışlar ile birlikte seyahat acentaları bu yöreyi ortak bir destinasyon olarak değerlendirmekte ve tur programları hazırlamaktadır. Bu sebeple çalışmada Burdur ve Isparta yöresinde öne çıkan turizm faaliyetleri ile birlikte bu bölgedeki turizm gelişiminin yönetim ve planlama çalışmalarını tespit etmek için turizm ile ilgili görevlerde ve çalışmalarda bulunan 16 katılımcı ile görüşmeler yapılmıştır. Görüşme sonuçları nitel araştırma yöntemlerinden betimsel analiz ve içerik analizi yapılarak veriler MAXQDA 2018 programı ile analiz edilmiştir. Çalışma sonuçlarına göre destinasyon yönetimi ile toplum temelli turizm temaları arasındaki ilişkiler incelenmiştir. Özellikle, yörede turizm faaliyetlerinin gelişmesi ile istihdam ve yerel yatırımların artacağı tespit edilmişti. Böylelikle, bölgenin ekonomik olarak güçlenmesi sağlanacaktır. Ayrıca, bölgede turizm sektöründe yapılacak yatırımlarda yerel girişimciliğe öncelik verilmesi ve yerel girişimciliğin desteklenmesi sonuçlarına da ulaşılmıştır. Bölgedeki turizm faaliyetlerinin doğal çevreye olan olumsuz etkilerinin önlemesi için planlama ve yönetim çalışmaları ile sürdürülebilir bir destinasyon yönetiminin önemi vurgulanmıştır.

* Bu çalışma Selçuk Üniversitesi Sosyal Bilimler Enstitüsünde “Destinasyon Yönetiminde Toplum Temelli Turizm Algısı: Burdur ve Isparta Yöresinde Bir Çalışma" adlı tez çalışmasından türetilmiştir.

Anahtar Kelimeler: Turizm Destinasyonu, Destinasyon Yönetimi, Toplum Temelli Turizm, Burdur ve Isparta Yöresi.

Makale Gönderme Tarihi: 02.07.2019

Makale Kabul Tarihi: 05.10.2019

\section{Önerilen Atıf:}

Sarı Gök, H. ve Ünüvar, Ş. (2019). Destinasyon Yönetiminde Toplum Temelli Turizm: Burdur ve Isparta Yöresinde Bir Araştırma, Türk Turizm Araştırmaları Dergisi, 3(4): 1055-1073.

(C) 2019 Türk Turizm Araştırmaları Dergisi. 


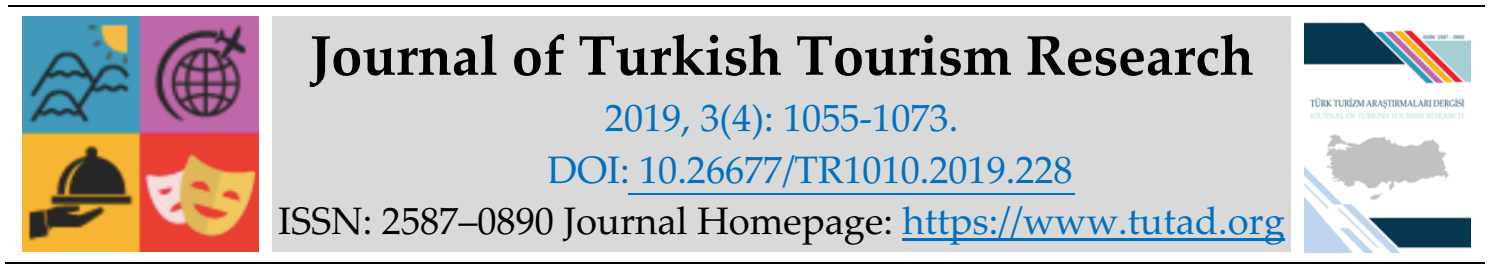

\title{
RESEARCH PAPER
}

\section{Community Based Tourism in Destination Management: A Research in Burdur and Isparta Region}

Lecturer Hatice SARI GÖK, Isparta University of Applied Sciences, Yalvaç Vocational School, Isparta, e-mail: haticesarigok@sdu.edu.tr ORCID: https://orcid.org/0000-0003-0949-2593

Associate Prof. Dr. Şafak ÜNÜVAR, Selçuk University, Faculty of Tourism, Konya, e-mail: safakunuvar@gmail.com

ORCID: https://orcid.org/0000-0001-9177-8704

\begin{abstract}
Being one of the alternative tourism models, community-based tourism is one of the strategies focusing on the society, aiming to benefit the local people more from tourism activities and supporting the control by local communities. In the community-based tourism model, several aspects such as the participation of local people in tourism planning and management within the region, bottom-up planning, supporting local entrepreneurship and qualifying the tourism activities in the region with a sustainable approach are highly important. In recent years, along with the increase in tourism demand in Burdur and Isparta region, travel agencies started to consider this region as a common destination and accordingly, arranged tour programs. In this regard, interviews were conducted with 16 participants in tourism related tasks and studies in order to determine the management and planning studies in tourism development and to present prominent tourism activities in Burdur and Isparta region. The results of the interviews were evaluated with descriptive analysis and content analysis, and the data were analyzed with MAXQDA 2018 software program. Consequently, the study examines the relationships between destination management and communitybased tourism themes. In particular, it was determined that employment and local investments would increase with the development of tourism activities in the region. Thus, economic strengthening of the region will be ensured. In addition, the results of prioritizing local entrepreneurship and supporting local entrepreneurship have been achieved in the investments to be made in the tourism sector in the region. In order to prevent the negative effects of tourism activities on the natural environment in the region, the importance of sustainable destination management is emphasized through planning and management studies.
\end{abstract}

Keywords: Tourism Destination, Destination Management, Community-Based Tourism, Burdur and Isparta Region.

Received: 02.07.2019

Accepted: 05.10.2019

\section{Suggested Citation:}

Sarı Gök, H. and Ünüvar, Ş. (2019). Community Based Tourism in Destination Management: A Research in Burdur and Isparta Region, Journal of Turkish Tourism Research, 3(4): 1055-1073.

(C) 2019 Türk Turizm Araştırmaları Dergisi. 


\section{Gíriş}

Destinasyondaki turizm gelişimi genellikle, güncel turizm trendleri, turizm işletmelerinin girişimleri, sivil toplum kuruluşlarının tutumu, hükümet ya da yerel yönetimlerin kararları ile şekillenmektedir. Yerel halkın kendi yaşamları ve gelecekleri ile ilgili turizm faaliyetlerinin planlanması ve geliştirilmesinde çok az kontrol sahibi oldukları görülmektedir (Pinel, 1998:1). Yerel halkın yaşadığı bölgenin turizm gelişiminde söz sahibi olması ve kendilerini turizmin bir parçası olarak hissetmeleri, o destinasyonda turizmin içselleştirilmesi, desteklenmesi ve sürdürülebilirliği açısından son derece önemlidir (Özdemir ve Kervankıran, 2011: 4). Toplumun sürecin içerisine çekilmesi bölgenin değerlerine sahip çıkılması ve çevreye karşı duyarlılığın artmasına da katkı sağlayacaktır.

Geleneksel yukarıdan aşağıya planlama yaklaşımlarından farklı olarak toplum temelli turizm; turizm gelişiminin türü, ölçeği ve yoğunluğu üzerinde yerel fayda, mülkiyet ve kontrol konuları üzerinde durmaktadır (Rozemeijer, 2001; Vajirakachorn, 2011). Yerel halk turizm planlaması ve gelişimine ilişkin karar verme süreçlerinde kontrolü elinde tutarak veya proaktif bir şekilde kontrolü sağlayarak kendi değerleri ve çıkarları doğrultusunda gelişmeyi yönlendirebilmektedirler (Johnson, 2010: 151). Toplum temelli turizmde toplum sakinleri bölgedeki turizm gelişiminin içerisine doğrudan dahil edilerek bölgedeki turizm faaliyetlerinin fikir aşamasından kontrol aşamasına kadar sürecin içinde yer alması sağlanmalıdır (Eagles, McCool, Stephen ve Haynes 2002: 46-48). Ayrica, turizm destinasyonlarında turizm yatırımlarının bölge dışından yapılan büyük ölçekli yatırımlar yerine yerel halkın yatırım yapmasının desteklenmesi yerel halkın ekonomik olarak güçlenmesine de katkı sağlamaktadır.

Kitle turizminin aksine toplum temelli turizm, destinasyonlarda toplum sakinlerinin turizmden gelir elde etmesi, küçük ölçekli işletmeler açması, yerel girişimcilik faaliyetleri, kooperatifler ve resmi makamlar tarafından turizmin yerel toplum içinde desteklenmesi üzerine odaklanmaktadır (Dunn, 2007; Goodwin ve Santilli, 2009). Bununla birlikte, toplum üyelerinin küçük ölçekli, insan merkezli yerel işletmeler açabilmesi; bölgede yoksulluğun azaltılması ve bölge için alternatif gelir kaynakları oluşturma imkanı da vermektedir (Taşçı, Semrad ve Yılmaz, 2013:6). Toplum temelli turizm; toplum sakinlerine istihdam, gelir artışı ve kalkınma olanakları sağlayarak, kültürel ve doğal güzelliklerin korunarak kullanılması ile birlikte turistlere de yerel toplum ile ilişkide bulunma fırsatı vermektedir (Choi ve Sırakaya, 2006).

Destinasyonlar için toplum temelli turizmin özelikle toplum sakinlerinin daha kaliteli bir yaşam sürmeleri ve bölgelerinin değerlerine sahip çıkmaları açısından önemli bir modeldir. Çalışmada Burdur ve Isparta yöresi turizm değerleri ile ortak bir destinasyon olarak ele alınmış ve bölgede turizm gelişimi ile ilgili toplum temelli turizm hakkında veri toplanmıştır. Çalışmada nitel araştırma yöntemlerinden görüşme tekniği ile 16 katılımcı ile görüşmeler gerçekleştirilmiştir. Çalışmada bölgenin turizm plan ve yönetiminde yerel halkın katılımı, aşağıdan yukarı planlama, yerel girişimciliğin desteklenmesi ve bölgedeki turizm faaliyetlerinin sürdürülebilirliği, toplum temelli turizm konuları ve bu konular arasındaki ilişkiler tespit edilmiştir.

\section{KAVRAMSAL ÇERÇEVE}

\section{Turizm Destinasyonu}

Fransızca kökenli bir kavram olan destinasyon; turistlerin en az bir gece konakladıkları fiziksel alan olan turizm destinasyonu, turistik ürünler (çekicilikler, turistik kaynaklar, diğer yan hizmetler) ile turistlerin alg1 ve imaj olarak kabul ettikleri, pazar ve yönetim rekabetini sağlayan fiziksel ve yönetimsel olarak sınırlandırılmış yerler turizm destinasyonu olarak nitelendirilebilir (Halmi ve Severoc, 2016:77). Buhalis'e göre (2000:97) destinasyon; "sahip olduğu özellikler ile turist çeken, turizm ürünlerinin birleşiminden oluşan bir ülke olabileceği gibi bir şehir, bir kasaba, bir ada, turizm 
merkezi gibi sınırları kesin olan coğrafi bölgelerdir." Kısaca "destinasyon" kavramı; varılacak olan yer, turistik mahal, turistik istasyon, turistik varış yeri, turizm çekim merkezi, turizm bölgesi gibi anlamlara gelmektedir (Atay, 2003:27).

Destinasyon; kültür, tarih, yaşama biçimi, dil, din gibi konularda birbirine yakınlığı olan toplumlar tarafından bir ülkenin veya bir kıtanın bir parçası olabilir. Bu nedenle destinasyon, kültürel, idari ve sosyal bir yer olarak görülmektedir. Turizm pazarındaki eğilimler ve bu eğilimlerdeki değişimlere göre destinasyon biçimleri ve sınırları değişebilmekte ve bu sınırlar belli bir süre için geçerlilik taşımaktadır (Tosun ve Jenkins, 1996:520; Usta, 2008:225; Güripek, 2013:46). Pike (2008) destinasyonu, siyasi olarak sınırları çizilmiş bir yerden ziyade, turistik kaynakların kümelendiği bir coğrafi alan olarak nitelendirmiştir. Buna göre, siyasi sinırlar ile tüm Türkiye'yi bir destinasyon olarak ele almak yerine, turistik kaynakların kümelendiği Kapadokya bölgesi, Akdeniz ve Ege kıyıları ve buralarda yer alan şehirleri destinasyon olarak ele almaktan söz etmektedir (Öztürk, 2013:3).

\section{Destinasyon Yönetimi}

Destinasyonlar farklı ihtiyaçlara sahip turistlere, turizm işletmelerine, çeşitli endüstrilere ve yerel halka cevap vermek zorunda olduğu için karmaşık bir yapıdadır ve bu durum destinasyon yönetimi ve gelişimini zorlaştırmaktadır. Destinasyon yönetimi, stratejik, örgütsel ve yönetimsel kararlardan oluşan turistik ürünlerin belirlenmesi, tanıtılması ve ticarileşme sürecini yönetmek ve turizm gelirlerinin dengeli, sürdürülebilir ve yerel halkın ihtiyaçlarını karşılayabilecek düzeyde olmasını sağlayacak bir sistem olmalıdır (Presenza, Sheehan ve Ritchie, 2005:2). Destinasyon yönetiminde, destinasyonlar için istenilen durumların oluşturulması ve istenmeyen etkilerin en aza indirilmesi için etkili bir yönetim modeli uygulanmalıdır (Güripek, 2013:56). Destinasyon yönetimi, bir destinasyonu oluşturan tüm unsurların (örneğin; çekicilik, turizm işletmeleri, ulaşım, pazarlama, fiyat) koordinasyonlu bir şekilde yönetilmesi amacı ile stratejik bir yaklaşım olarak ele alınmalıdır (Halmi ve Severoc, 2016:77). Destinasyon yönetiminde destinasyonlarda sunulan turistik mal ve hizmetlerin kalitesini arttırarak rekabet üstünlüğü sağlayacak bütünleşik bir yaklaşım kullanılmalıdır (Cabael, 2011:21). Bununla birlikte, turizm sektöründe rekabetin artması ve bölgesel rekabet edebilmek ve bölgesel işbirliğinin daha bilinçli ve etkin yürütülmesi için diğer bölgelerle "işbirliğine dayalı stratejiler" ve bölgesel pazarları kontrol edebilmeye yönelik "bölgesel yoğunlaşma stratejilerinin" izlendiği modern destinasyon yönetim sistemleri oluşturulmalıdır (Dávid ve Tözsér, 2009:81).

\section{Toplum Temelli Turizm}

Toplum temelli turizm kavramı, ilk olarak 1970'lerde kalkınma söylemlerinde yeni bir paradigma olarak ortaya çıkmıştır. Özellikle az gelişmiş ve gelişmekte olan ülkelerde kitle turizminin negatif etkilerinin azaltılması için toplum temelli turizm çözüm yollarından biri olarak öngörülmüştür (López-Guzmán, Sánchez-Cañizares ve Pavón, 2011:37; Zapata, Hall, Lindo ve Vanderschaeghe, 2011:726). Kitle turizminin toplumsal fayda ve çevre korumaya yönelik beklentileri karşılayamaması (Goodwin ve Santilli, 2009; Demers, 2011; Giampiccoli ve Kalis, 2012) sürdürülebilir turizm ve sorumlu turizm kavramları ile açıklanan ve aşağıdan yukarı gelişmeyi hedefleyen yeşil turizm, tarım turizmi, eko-turizm, yoksul yanlısı turizm, sosyal turizm, gönüllü turizm ve toplum temelli turizm gibi yeni turizm türlerini ve modellerini gündeme getirmiştir (Taşçı, Semrad ve Yılmaz, 2013:6). Sürdürülebilir turizm gelişimini sağlamaya yönelik bu modeller temelde yoksullukla mücadele, çevrenin korunması, demokrasi, iyi yönetişim gibi ilkeleri hedeflemektedir (Zapata vd., 2011:727; Taşçı vd., 2013:6). 
Toplum temelli turizm kavramının çeşitli tanımları mevcuttur. Suansri (2003:14) toplum temelli turizmi; yerel halkın ekonomik, sosyal, çevresel ve kültürel sürdürülebilirliğini dikkate alan, yerel kaynak ve değerler hakkında onların farkındalığını artıran, yerel yaşam yolları ile turizmden fayda elde etmelerine imkân sağlayan, yönetimin, mülkiyetin ve kontrolün yerel halkta olduğu sürdürülebilir bir araç olarak tanımlamıştır. Boonratana (2010:286) ise toplum temelli turizmi; yerel halkı; yerel kaynak, ürün ve değerlerinin farkına vararak gurur duymasını sağlayan, bunların turizmden gelir sağlamak üzere geliştirilmesine yardımcı olan, topluluğun aktif katılımıyla yönetilen, turistlerin ekonomik, çevresel, sosyal ve kültürel açılardan sorumlu olduğu sürdürülebilir turizm türü olarak tanımlamıştır. Toplum temelli turizm, kırsal alanda temelde alternatif ekonomik faaliyetler için fırsatlar sağlamaktadır. Kırsal toplumlardaki özellikle kadınlar, gençler ve çeşitli beceri ve tecrübelere sahip insanlar için yeni iş kolları ve girişimcilik fırsatları oluşturmak için önemli bir potansiyele sahiptir (Harris ve Vogel, 2007:5; López-Guzmán vd., 2011:70; Giampiccoli ve Kalis, 2012:175). Toplum temelli turizmde turizmden elde edilen faydanın yerelleştirilmesi ile birlikte bölgeden dışarıya göçün azaltılması, yeni iş imkanlarının ortaya çıkması, sosyo-ekonomik sorunların azaltılmasında yerel halkın katılımı ön koşul kabul edilmektedir (Abdulrazzag, Mustafa, Amran, Khalifah ve Mohamad, 2011:1836).

Toplum temelli turizm ile ilgili yapılan çalışmalar arasında; Hiwasaki (2006) Japonya'nın koruma bölgelerinde toplum temelli turizm üzerine yaptığı çalışmasında toplum temelli turizm ile ilgili dört başarı kriteri belirlemiştir. Dunn (2007) kırsal bir Taylandlı topluluk olan Leeled'in toplum temelli turizm projesi ile kadınların güçlendirilmesini nasıl desteklediğini araştırmıştır. Kibicho (2008) çalışmasında; toplum temelli turizmin başarı faktörlerini belirlemiştir. Zapata vd. (2011) çalışmalarında toplum temelli turizm modelinin Nicaragua vakasında sosyo-ekonomik kalkınmayı ve yoksulluğun azaltılması konusundaki uygulanabilirliğini incelemiştir. Pookaiyaudom (2012) toplum temelli turizmin arz yönü ile birlikte yerli ve yabancı turistler açısından yani tüketici açısından incelemiştir. Karacaoğlu, Yolal ve Birdir (2016) çalışmalarında; Bursa'nın Misi Köyünde başlatılan toplum temelli turizm projesinin algılanan fayda ve maliyetlerinin incelenmesi ve projenin yarattığı fayda ve maliyetlerin topluluk üyeleri arasında nasıl paylaşıldığını incelemişlerdir.

Sonuç olarak; toplum temelli turizm özellikle kırsal bölgelerde yerel halkın olağan ekonomik faaliyetleri arasına turizm faaliyetlerinin de dahil edilmesi ve böylece yerel halkın ekonomik olarak güçlenmesi, yoksulluğun azaltılması ve bölgeden dışarıya yaşanan göçün azaltılması konularında katkılar sağlamaktadır. Konu ile ilgili yapılan araştırmalarda toplum temelli turizm konusu farklı açılardan değerlendirilmiştir. Özellikle kırsal bölgeler toplum temelli turizm projeleri (Dunn, 2007; Zapata vd., 2011), toplum temelli turizm başarı kriterleri (Hiwasaki, 2006; Kibicho, 2008), toplum temelli turizm girişimleri (Goodwin ve Santilli, 2009) ve turizm endüstrisinin toplum temelli turizm ile canlandırılması (Jones, 2016) konuları örnek verilebilir. Alan yazında destinasyon yönetimde toplum temelli turizm konulu çalışmaların yetersiz olması ve bölgelerdeki turizm faaliyetlerinde yerel halka yatırım yapma, istihdam, girişimcilik faaliyetlerinde öncelik verilmesi ve turizm plan ve yönetiminde yerel halkın katılımı konuları üzerinde durulmuştur.

\section{YÖNTEM}

\section{Çalışma Alanı ve Katılımcılar}

Burdur ve Isparta illerinde benzer ve farklı özellikteki turist değerleri ile görülmeye değer destinasyonlar arasındadır. Son yıllarda tanıtım çalışmalarına ağırlık verilmesi ve sosyal medyanın etkisi ile bölgeye olan turizm talebinde ciddi artışlar yaşanmıştır. Sagalassos, Kibyra, Pisidia Antiocheia'sı gibi antik kentleri, Kovada Gölü, Salda Gölü, Eğirdir Gölü, lavanta 
bahçeleri, gül bahçeleri, sakin şehirleri, İnsuyu, Zindan, Pınargözü gibi mağaraları ve daha birçok turistik değerleri ile bölgeye olan turistik talep her geçen gün artmaktadır. Yakın iller olması sebebiyle seyahat acentaları tarafından gerçekleştirilen konaklamalı tur programlarının sayısı da her geçen gün artmaktadır. Bu sebeple çalışmada Burdur ve Isparta yöresi bir destinasyon olarak düşünülmüş ve çalışma alanı Burudur ve Isparta yöresi olarak belirlenmiş ve sınırlandırılmıştır. Burdur ve Isparta yöresinde destinasyon yönetiminde toplum temelli turizm ile ilgili veri toplamak için nitel araştırma yöntemlerinden görüşme tekniğinden yararlanılmıştır. Görüşmeler Isparta ve Burdur yöresinde turizm ile ilgili kamu kurumları, özel sektör temsilcileri, sivil toplum kuruluşları üyeleri, akademisyenler, yerel yöneticiler ve Batı Akdeniz Kalkınma Ajansı (BAKA) uzmanı (Tablo 1) ile 1 Temmuz 2018- 31 Ocak 2019 tarihleri arasında gerçekleştirilmiştir. Literatürde nitel çalışmalarda örneklemi oluşturacak öge sayısının 5 ile 25 arasında değişebileceği belirtilmektedir (Patton, 2005; Neuman, 2014; Rubin ve Babbie, 2016). Çalışmada, gönüllü 16 katılımcı ile görüşmeler yapılmış ve her katılımcıya bir kod (K 01, K 02) verilmiştir.

Tablo 1. Görüşmeye Katılan Katılımcılara İlişkin Tanımlayıcı Bilgiler

\begin{tabular}{|l|l|l|}
\hline Katılımcı 1 (K01) & Kamu & $\begin{array}{l}\text { Lavanta Kokulu Köy } \\
\text { Projesi Koordinatörü }\end{array}$ \\
\hline Katılımcı 2 (K 02) & Kamu & Enformasyon Memuru \\
\hline Katılımcı 3 (K 03) & Otel İşletmesi & Önbüro Müdürü \\
\hline Katılımcı 4 (K 04) & Kamu & Şube Müdürü \\
\hline Katılımcı 5 (K 05) & Üniversite & Ögretim Üyesi \\
\hline Katılımcı 6 (K 06) & Belediye & Zabıta müdürü \\
\hline Katılımcı 7 (K 07) & Belediye & Belediye Başkanı \\
\hline Katılımcı 8 (K 08) & Seyahat Acentası & İşletme Müdürü \\
\hline Katılımcı 9 (K 09) & BAKA (Batı Akdeniz Kalkınma Ajs) & Uzman \\
\hline Katılımcı 10 (K 10) & Belediye & Belediye Başkanı \\
\hline Katılımcı 11 (K 11) & Belediye & Beld Çalışanı/Cittaslow \\
\hline Katılımcı 12 (K 12) & Üniversite & Öğretim Üyesi \\
\hline Katııımcı 13 (K 13) & Otel İşletmesi & İşletme Müdürü \\
\hline Katılımcı 14 (K 14) & Sivil Toplum Kuruluşu & STK Üyesi \\
\hline Katılımcı 15 (K 15) & Sivil Toplum Kuruluşu & STK Üyesi \\
\hline Katılımcı 16 (K 16) & Yiyecek-İçecek İşletmesi & İşletme Sahibi \\
\hline
\end{tabular}

\section{Veri Toplama}

Veri toplama aşamasında nitel araştırmalarda en yaygın kullanılan teknik olan (Yıldırım ve Şimşek, 2016) olan yüz yüze görüşme tekniği kullanılmıştır. Görüşme tekniği, bireylerin belirli bir konu hakkında sahip olduğu bilgi, tutum ve düşüncelerinin öğrenilmesini sağlayan veri toplama tekniği olarak tanımlanmaktadır (Karasar, 2015). Araştırmada, yarı-yapılandırılmış bir görüşme formu hazırlanmıştır. Araştırma formunda uzman görüşleri ile hazırlanan yar1yapılandırılmış mülakat soruları yer almaktadır. Görüşme formunda temel soruların yanı sıra ilave hatta önemli sayılabilecek alt kategorilere göre sorular da kullanılmıştır. Görüşmede kullanılan açık uçlu sorular aşağıda verilmiştir;

\section{Sorular}

1. Burdur ve Isparta yöresi iklimi, doğal, tarihi ve kültürel kaynakları, gelenek görenekleri ile turizme elverişli bir durumda mıdır? 
2. Bölgede turizmde doğrudan ve dolaylı olarak hizmet veren işletmelerin durumu nasıl, sayısı ve hizmet kalitesi yeterli mi?

3. Bölgede yapılan yatırımlar bölge dışından $\mathrm{mı}$ yoksa yerel halk tarafından $\mathrm{m} ı$ gerçekleşmektedir?

4. Bölgede yapılacak yatırımlarda yerel halka öncelik verilmekte midir?

5. Bölgede bulunan turizm işletmelerinin yerel halka iş imkanı sağlama durumu nedir?

6. Burdur ve Isparta yöresinde turizm planlama ve yönetim süreçleri hakkında ne düşünüyorsunuz?

b. Yerel halkın turizm plan ve yönetimine katılımı nasıl sizce yeterli midir?

7. Bölgede turizmin gelişmesiyle birlikte ekonomik, sosyo-kültürel ve çevresel nasıl etkiler oluşmuştur?

8. Toplum temelli turizm hakkında ne düşünüyorsunuz?

Görüşme sırasında elle notlar alınmış ve katılımcılardan izin alınarak görüşmeler kayıt altına alınmıştır. Görüşmelere ait ses kayıtları daha sonra değişiklik yapılmadan yazıya aktarılmıştır. İlk olarak Isparta İl Kültür ve Turizm Müdürlüğ̈̈'nden uzman bir yetkili ile görüşülmüş ve pilot çalışma gerçekleştirilmiştir. Pilot çalışma ile soruların anlaşılıp anlaşılmadığı, cevapların çalışmanın amacına ve önemine uygun olup olmadığı tespit edilerek gerekli düzeltmeler yapılmıştır.

\section{Veri Analizi}

Görüşme sonuçlarına betimsel analiz ve içerik analizi yapılmıştır. Betimsel analizde görüşülen ya da gözlenen bireylerin görüşlerini çarpıcı bir şekilde yansıtmak amacıyla doğrudan alıntılara sık sık yer verilir (Yıldırım ve Şimşek, 2016:238). Çalışmada da görüşmeye katılan bireylerin görüşlerine sık sık yer verilerek elde edilen bulguların düzenlenmiş ve yorumlanmış bir biçimde okuyucuya sunulması amaçlanmıştır. Nitel araştırmaların analizi, zor, karmaşık, uzun ve zaman alıcıdır; ayrıca öncelikle tümevarımcıdır (Daymon ve Holloway, 2005:232). Bu sebeple, bazı gizli kalmış ve anlaşılmayan kavramlar üzerinde kısmen içerik analizi uygulanmıştır. İçerik analizi yapılırken, birbirine benzeyen verileri belirli kavramlar ve temalar çerçevesinde bir araya getirmek ve bunları okuyucunun anlayabileceği bir biçimde düzenleyerek yorumlanmalıdır (Yıldırım ve Şimşek, 2016:242). Araştırma sorularına göre ortaya çıan bazı cümle ve paragraflar genel bir çerçeve içinde ortak özelliklere ayrılarak kodlanmış ve kavramsallaştırılmıştır. Daha sonra görüşmecilerden elde edilen bulgular tematik kodlamaya göre düzenlenmiş ve tanımlanmıştır. Görüşme sonuçları bilgisayara aktarılmıştır. Katılımcılarla yapılan görüşmeler, profesyonel bir bilgisayar destekli veri analiz programı (Computer Assisted Qualitative Data Analysis Software/CAQDAS) olan MAXQDA 18 ile analiz edilmiştir. Nitel araştırma verilerinin analizinde Kod-alt kod frekans grafikleri ile bir kodun alt kodları ile birlikte katılımcı ifade sayılarına göre sonuçları verilmiştir. Ayrıca, İlişki haritası çıkarılarak, katılımcıların konuşmaları esnasında birbiri ile bağlantılı olarak aynı cümle ya da paragraf içinde bahsettikleri konuları gösterilmiştir.

Araştırmanın güvenirliliğini sağlamaya yönelik birincil ölçüt, görüşme formunun üç akademisyen (kapsam geçerliliği açısından) ve ifadelerin bir uzman görüşü ile teyit edilmesidir. Güvenirliliğe yönelik bir diğer ölçüt de katılımcıların (birinci kaynaktan) görüşlerinin doğrudan aktarılmış olmasıdır. (Yıldırım ve Şimşek, 2016:270-271). Çalışmada görüşme formu üç akademisyen ile teyit edilmiştir. Ayrıca katılımcıların görüşleri doğrudan herhangi bir değişiklik yapılmadan aktarılmıştır. Ayrıca araştırmanın güvenirliliği için alanda uzman iki kişi tarafından değerlendirilmiş ve kodlar arası eşleşmeler olduğu görülmüştür. Şencan (2005), nitel çalışmalarda güvenirliliğin 0.40 değeri ile 0.75 değeri arasında hesaplanan değerin makul bir değer olduğu ve uyuşmanın sağlandığı belirtilmiştir. Çalışmanın güvenirliliği için MAXQDA 18 
programında Kappa testi yapılmış güvenirlilik 0.75 bulunmuştur. Yapılan güvenirlilik analizi ile kodlayıcılar arasında bir uyuşmanın sağlandığı tespit edilmiştir.

\section{BULGULAR}

"Burdur ve Isparta yöresi iklimi, doğal, tarihi ve kültürel kaynakları, gelenek görenekleri ile turizme elverişli bir durumda mıdır?" sorusuna katılımcılar; Isparta ilinin turizm değerleri olarak Davraz Dağı, Pisidia Antiocheia'sı, Yazılı Kanyon, Gölcük Milli Parkı, Kovada Gölü, Eğirdir Gölü; Burdur'un Karacaören Barajı, Sagalassos, Kibyra, Salda Gölü, İnsuyu mağarası gibi turizm değerlerinden bahsetmişlerdir. Ayrıca önemli bir diğer tespitte şu şekildedir;

Turizm deyince ülkemizde ve dünyada herkes kitle (mass) turizminden bahsederken artık alternatif turizm çeşitleri de sık sık gündeme gelmektedir. Alternatif turizm açısından bizim bölgemiz bir turizm destinasyonu olarak çok önemli bir yerlere sahiptir. Insanlar deniz, kum ve güneş turizmden ziyade artık kültür turizmine, doğa turizmine ve agro dediğimiz tarım turizmi ile gastronomi turizmi dediğimiz yörelerin eski mutfaklarma yönelmektedir (K 14).

Bölgenin turizm değerleri açısından; Sütçüler doğa turizminde eşsiz bir yerdi oradaki tıbbi aromatik bitkiler başlı başına eşsiz bir turizm malzemesidir. En güzel o ana kadar işleyen kısmı bundan 20 yıl öncesine kadar Eğirdir, yine 10- 20 yıl öncesi de Yalvaç Antiocheia turist çekiyordu. Bir Gölcük Isparta noktasında bir değer ihtiva ederken maalesef hiçbir şekilde bir kaynak olarak kullanılamadı. Bölgede turizm eskiden kendi haline bırakılmış bir değerdi ve son bir kaç yıla kadar hiç bilinmeyen zengin turistik değerlere (Salda Gölü, Sagalassos, Lavanta turizmi, Gül Turizmi vb.) sahiptir... (K 09)

Katılımclar son yıllarda bu bölgeye olan turizm talebinde ciddi artışlar yaşandığını belirtmişlerdir. Bu artışın arkasındaki en önemli etkenler arasında; lavanta bahçeleri, gül bahçeleri ve Salda Gölü'nün etkili olduğunu belirtmişlerdir.

"Bölgede turizmde doğrudan ve dolayl olarak hizmet veren işletmelerin durumu nasıl, sayısı ve hizmet kalitesi yeterli mi?" sorusuna katılımcılar Burdur için yetersiz olduğu ve hizmet kalitesi açısından zayıf olduğu ifade edilmiştir. Yakın iller olası sebebiyle Burdur'un konaklama ihtiyacının büyük bir kısmının Isparta'nın karşıladığı söylenmiştir. Yeşilova'da (Salda Gölü) yeni yeni pansiyonlar açılmaya başlanmış olmasına rağmen özellikle Yeşilova'nın konaklama ihtiyacını karşılayamadığı ifade edilmiştir.

Salda Gölü'nde bir belediyenin iki tane de şahsa ait restoran var, on odalı belediyenin bir oteli, üç yıldızlı bir şahıs oteli, pansiyonlar, belediyenin yirmi adet bungalovları, halkın çadırları var yerel halk bu çadırlarını günlüğ̈̈ 30 TL'ye kiraya veriyor ama konaklama ihtiyacın tam karşılayamıyor. Aynı zamanda çadırları ile gelenler de kamp alanımızda çadırlarını kurup burada kalabiliyor...(K 06)

Isparta'da özellikle konaklama işletmeleri açısından 2017 yılında Ramada ve Hilton otellerinin açılması ile konaklama ihtiyacının büyük oranda çözüldügü ifade edilmiş. Isparta'da son birkaç yılda hem büyük ölçekli hem de küçük ölçekli turizm işletme sayısında artışlar olmuştur, özellikle Kuyucak Köyü'nde.

Birçok işletme var, şu an bu işletmeler bu köy için çok eski işletmeler değil 2 yıllık işletmeler. Köyde öncelikle bir kadın kooperatifi kurduk ilk yıl, önce köylüler bir baktılar, hani bu olacak mi diye, ne olacak diye ilk sene izlediler. İkinci sene, 5-6 tane işletme kuruldu, (Restorantlar, pansiyonlar (Şuan 10'a yakın pansiyon var)). 30'a yakın satış işletmesi var. Onun dışında bahçelerin içinde birçok işletmeler var. Maliyeye kayıtlı resmi kayıtlı işletmeler tabi bunlar çeşitlilik göstermekte. Bir kısmı sadece satış yapıyor, bir kısmı pansiyonculuk, bir 
kısmı kırsal turizm yapıyor. Lavanta Kokulu Köy projesi ile önce tanıtım yapıldı daha sonra işletmeler kuruldu. İşletme tanıtımı değil de köyün tanıtımı yapıldığı için işletmeler de bundan payını alıyor şuan için. (K 01)

"Bölgede yapılan yatırımlar bölge dışından $m \imath$ yoksa yerel halk tarafından $m \imath$ gerçekleşmektedir?" sorusuna katılımcıların çoğunluğu yatırımların büyük çoğunluğunun yerel halk tarafından yapıldığını ifade etmişlerdir. Yalnız yatırımlar konusunda değişik fikirleri olan katılımcılar vardır. Örnek vermek gerekirse;

Yapılan yatırımlar yerelden yapıldı. Dışarıdan gelip de yatırım yapan işletme olmadı. Çok istedim aslında Barida oteli de istedim, yatırımcısına gelin artık dedim. Ama maalesef olmadı. Dışarıdan yatırımın gelmesini istiyorum çünkü bir profesyonel işletmenin buraya gelerek yerel işletmelere öncü ve örnek olmasın istiyorum. Yerelden ciddi anlamda turizm konusunda bir sahiplenme olmadı. Ana cadde de sadece gül sezonunda bir canlilik dahi olsa yeterliydi... (K 10)

"Bölgede yapılacak yatırımlarda yerel halka öncelik verilmekte midir?" sorusuna yapılacak yatırımlarda yerele öncelik verilmesi gerektiği ağırlıklı olarak ifade edilmiş ama turizmin, hizmet kalitesinin, müşteri memnuniyeti konularının bilinmesi ve yapılan yatırımların sürdürülebilir olması gerektiği ifade edilmiştir. Katılımcılardan bazıları ise ilk yatırımların dışarıdan profesyonel bir işletme ile yapılması ve bunun yerele öncü olması açısından önemli olduğunu ifade etmiştir.

\begin{abstract}
Ekonomik anlamda girdinin burada kalması önemli bir nokta. Dışarıdan bir yatırımcının yatırım yapıp da kaynă̆ın başka bir yere gitmesi bu yöre için iyi olmaz. Bana kişisel görüşümü sorarsanız ben dışarıdan profesyonel bir yatırımcının hepsinin değil ama örnek nitelikte, hepsini temsil edebilecek profesyonel bir yatırımcının gelerek yereldeki insanlara örnek olması stratejisi daha güzel olabilir. Çünkü neden yereldeki insan tamam güler yüzlü olabilir ama turizmi, hizmet kalitesini, müşteri memnuniyetini bilmiyor... (K 09)

Ilk hareketi mesela büyük sermaye dışardan gelenler başlatabilir ama sonrasında buradaki yereldeki insanlarm yürütmesi lazım. Niye çünkü hep onlar işin başında hem de yaşayarak yapıyorlar... (K 11)

Öncelik yerel halka mı verilmeli dediğinizde yani yerel halk bu işin içinde ne kadar olmak istiyor. Onu da sorgulamak lazım yani bu işin içinde olmaktan kastım şehrine bu yatırımı yaptığı zaman istihdama katkısı ne olacak, buradaki üreticilerin ürünleri değerlendirilmesi konusunda ne tür katkısı sağlayacak. Şehrinin bölgesinin tanıtılmasına ne tür katkısı olacak bu açıdan değerlendirildiğinde dışardan gelecek yatırımcıya nazaran yerel yatırımcının etkisi daha fazla olur. Ama bu yüzde yüz böyle olacak anlamında değil. O nedenle bu beklentileri ya da yani memleketini şehrini sevmesi lazım. Bir yerde memleketine hizmet olarak düşünüyorsa önceliği yerel halka verilmesinin daha uygun olacă̆ını düşünüyorum... (K 12)
\end{abstract}

"Bölgede bulunan turizm işletmelerinin yerel halka iş imkanı sağlama durumu nedir?" sorusuna bölgedeki turizm işletmelerinin yerel halka istihdam sağlamada katkısı olduğunu çoğu katılımcı ifade etmiştir. Bu katkılar işletmelerin büyüklügüne göre değişmektedir. Özellikle Kuyucak Köyü, Yeşilova (Salda Gölü), Güneykent'te kadınlara iş imkanı sağladığına dair ifadeler vardır. Kalifiye elemanın Antalya'ya gittiği ve işletmelerin dışarıdan gelen personele lojman vs. konaklama imkanı sağlamaması nedeniyle de kalifiye elemanın olmadığı ifade edilmiştir. Ayrıca personele düşük ücretler verildiği bunun da düşük hizmet kalitesi olarak döndüğü ifade edilmiştir.

Evet yerel halka iş imkanı kesinlikle sağlıyor. Bizim otelimizde 120 kişi çalışıyor. Örneğin Kuyucak'taki satışlar özellikle o bölgeye iş imkanı ve ekonomik gelir sağlıyorlar... (K 03)

Antalya'ya yakın olması kalifiye eleman Antalya'ya kayıyor, bu nokta da halkı bilinçlendiriyoruz. Ama maalesef kalifiye eleman buradaki şartlardan ve düşük ücretten dolayı Antalya'ya kayıyor...(K 04) 
Evet muhakkak sağlar. Ama maalesef çok fazla yatırım yok. Özelikle kadınlara iş imkanı sağlaması noktasında yaptığımız çalışmalar var. Gül evi açtık burada kadınlara ĕ̆itimler vererek, Geçmişe Dokunan Halı Dokuyan Eller projesi yaparak Isparta'nın kaybolan değeri olan Isparta Halısını canlandırmak ve farkındalık oluşturmak istedik, ev hanımlarına istihdam sağladık. Gülderen Kadın Kooperatifini kurarak kadınlara halı, iğne oyası, gül ürünleri, atık materyellerden hediyelik eşya ve tarımsal ürünlerin ekonomik değerinde satış ve pazarlanması için çalışmalar yaptık... (K 10)

"Burdur ve Isparta yöresinde turizm planlama ve yönetim süreçleri hakkında ne düşünüyorsunuz?" sorusuna bölgedeki turizm ile ilgili yapılan planlamalarda süreklilik olmadı̆̆1 ve yöredeki üst kademe yöneticilerine göre (Valiler, Kaymakamlar ve Belediye Başkanları) plan ve politikaların şekillendiği ifade edilmiştir. Bu yöneticilerin değişmesi sebebiyle yapılan çalışmaların yarım kaldığı, sürdürülebilir ve uzun süreli bir planlama olmadığı, planların bir yıllık süreyi aşmadı̆̆ı belirtilmiştir.

Ne turizm planlama ne de yönetim süreçleri var. Yeni yeni yapacağız diye uğraşıyoruz. Yöneticiler çabuk değişiyor. Bizim kaymakam 1,5 yılda değişti, eski kaymakam da yaklaşık aynı süre içinde değişsi. Süre kısa olunca planlama falan yapılamıyor. Bir yönetici gidince işler yarım kalıyor. Yeni gelen onun çalışmalarını devam ettiremeye biliyor... (K 07)

Bölgedeki turizm planları gayri resmi planlarla hareket ediliyor. Valilik koordinasyonunda bütün faaliyetler gidiyor. Fakat valiler değişiyor çalışmalar yarım kalabiliyor. Kültür turizm müdürlükleri, kalkınma ajansı, sanayi ve ticaret odası, ilçe belediye başkanları, kaymakamlardan muhtarlara kadar, bölgede faaliyet gösteren dernekler, otelciler, acentalar, girişimciler ile birlikte hareket etmeye çalışıyoruz. En büyük eksiklik, 2015 yılında ilçelerde Kırsal eylem planları diye bir çalışma başlatmışıı bir önceki valimiz ile birlikte Kırsal Kalkınma ile ilgili ilçelerde toplantılar yaptık bunun sonrasında da kırsal turizm ile alakalı strateji ve eylem planı yapma çalışmamız vardı ama gerçekleşemedi... (K 09)

Salda Gölü'nde bir koruma imar planı oluşturulması konusunda Çevre ve Şehircilik Müdürlüğ̈̈ ile ortak çalışmamız var. Bakanlığımızın da (Kültür ve Turizm Bakanlığı) mali desteği ile belli bir bütçe geldi bakanlıktan, Salda Gölü koruma imar planı yok şu anda, sit alanları tekrar belirlenecek, sit alanlarında yapacağını her türlü işlem izne tabi oluyor. Insanlar geliyor, lavabo, soyunma kabini, yeme-içme tesislerinin yapılması ile ilgili planlamaların yapılması gerekiyor... (K 04)

"Yerel halkın turizm plan ve yönetimine katılımı nasıl, sizce yeterli mi?" sorusuna katılımclar turizm plan ve yönetimine yerel halkın katılımının hem olduğunu hem de olmadığını ifade etmişlerdir. Türkiye' de yukarıdan aşağıya doğru bir planlama olduğunu yani turizm planlarının daha çok merkezi yapıldığını ve merkezden uzmanların bölgelere gelip çalışmalar yaparak planlamaların gerçekleştiğini ifade etmişlerdir. Bazı bölgelerde ise yerel halkın planlama çalışmalarına çok aktif katılımının olmadığı ve turizm destinasyonu anlamında planlama ve yönetim yapabilecek bir güce sahip olmadıklarını ifade etmişlerdir. Yerel halkın nihai karar konusunda çok fazla söz sahibi olmadığını ancak, fikirlerin ortaya atılmasında, kararların alınmasında ve uygulama aşamasında bir şekilde değerlendirilip sürece aktif katılımın sağlanmasının öneminden bahseden katılımcılar olmuştur. Geniş çaplı halkın dahil olduğu organizasyonlar ve toplantıların yapılması gerekmektedir. Eğer bu şekilde geniş katılım sağlanır ise yerel halkta turizm olayına sahip çıkılabileceği ifade edilmiştir. Bu soruya farklı bir bakış açısı ile dikkat çekilmiş ve yerel halk, kamu kurumları, esnaf ve turizmcilerin katılımı ile toplantılar gerçekleşmekte olduğu yalnız sadece fikirler alınıp, raporların tutulduğunu ama bir adım ileri gidilmediğinden bahsedilmiştir. Bunların maalesef kağıt üzerinde kaldığına yönelik serzenişte bulunulmuştur.

Yerel halkın katılımı konusunda Güneykent'te; kadınların turizm ile ilgili çalışmalara katılımının daha fazla olduğunu belirtmişlerdir. Gülanta Çalıştayı yaptık katıldılar. Yapılan projelerin eğitim programlarına katıldılar. 
Ayrıca gezi programlarımıza katılım var. Bayanlar mükemmel ama erkekler noktasında bu konuda çok katılım yok... (K 10) Ayrıca Kuyucak'ta yerel halkın katılımının olduğu bunun sebebinin de yerel halk tarafindan kurulmuş bir çok işletme olduğu için plan ve yönetimi de bunlar kendi aralarında bir şekilde yapıyorlar. Tabi üst kademe de ilk başta yapılan şeylere şuan yerel halk da uyum să̆lıyor. Yerel halkın görüşü alınıor mutlaka...(K 01) Turizm plan ve yönetimine yerel halkın katılımı konusunda bölgeler arasında farklılıklar olduğu ortaya çıkmıştır.

Şekil 1'de bölgedeki turizm plan ve yönetimine yerel halkın katılımı ile ilgili ifadelere yer verilmiştir. Kuyucak Köyü'ne "Lavanta Kokulu Köy" projesinin sağladı̆̆ı katkıların oldukça fazla olduğu ifade edilmekle birlikte bölgede yapılan çeşitli projelerin sürekli olmadı̆̆ı ifade edilmiştir. Bununla birlikte, bölgede yapılan yeni projelerin olduğu ve sivil toplum kuruluşlarının projelerde kişilere ve işletmelere yardımcı olduklarını ifade etmişlerdir. Bölgedeki turizm planlamaları ile ilgili çalışmalarda yöneticilerin hızlı değişmesi, yerel halkın plan ve yönetime katılımının fazla olmadığı yönünde olumsuz ifadeler de yer almaktadır. Ayrıca, turizm ile ilgili yapılan toplantılarda kimsenin konuyu tam bilmediği de ifade edilmiştir. Yönetim ve planlama çalışmalarının yapılabilmesi için proje ofislerinin kurulması ve fikirleri olan kişilerin bu ofislere başvurular yaparak yardım almasının iyi olabileceği belirtilmiştir.

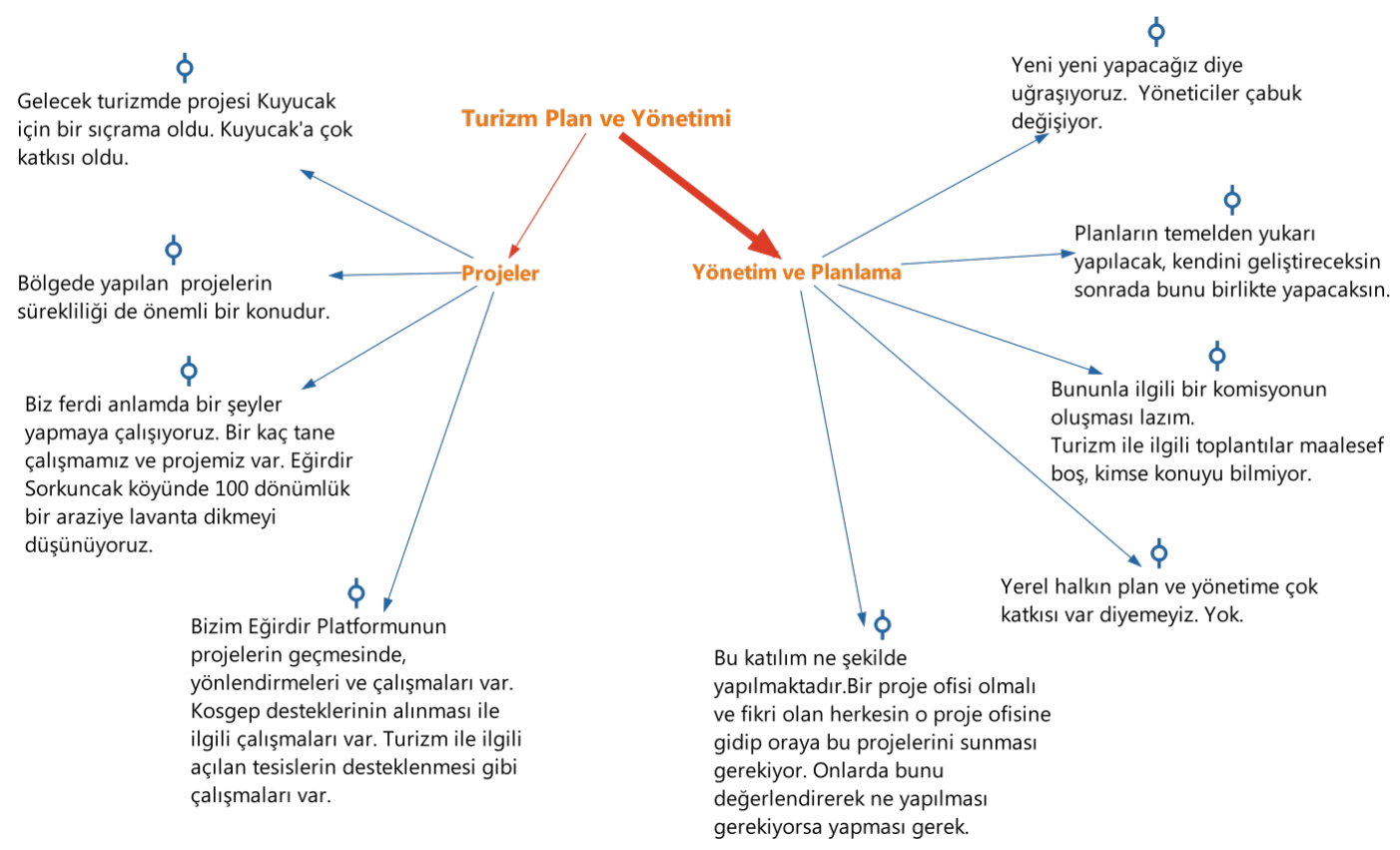

Şekil 1. Burdur ve Isparta Yöresinde Turizm Plan ve Yönetime İle İlgili İfadeler

Bu konuda farklı görüşlerde tespit edilmiştir. Örnek vermek gerekirse;

Bu konuda Burdur halkının olumlu işler yapacă̆ını düşünüyorum. Biraz yönlendirilmesi gerekiyor. Her şey gelir olarak gördükten sonra daha aktif olur. Alt yapıyı ve o turizmin özellikleri dikkate alınmadan hemen Salda Gölü'nün kıyısına bir beş yıldızlı otel dikelim diyorlar en son katıldı̆̆ımız toplantıda. Sürdürülebilir olması gerekir Salda'nın. Uzungöl gibi olmasın, Uzun Gölde Arap turistler gelip fotoğraf çekip gidiyor, betonlaştı. Şuanda orası ile alakalı bir planlama falan yok gördüğümüz, belki de yerel yönetimlerin eli bağhı bilmiyoruz. Yerel yönetimlerin bu noktada daha çok çalışması gerekiyor... (K 05) 
Şekil 2'de turizme yerel halkın katılımı teması altında; istihdam, yerel girişimcilik ve kooperatifler alt kodları oluşturulmuştur. Güneykent'te, Kuyucak Köyü'nde ve Salda Gölü'nde turizm hareketleri ile yerel halka iş imkanı sağladığı ifade edilmiştir. Dışarıdan personel için lojman vs. gibi ihtiyaçların işletmeler tarafından karşılanmadığı belirtilmiştir. Özellikle bu bölgelerde kadınlara yönelik istihdam çalışmaları yapılarak kadınların ekonomik kazanç elde etmelerine yardımcı olunmuştur.

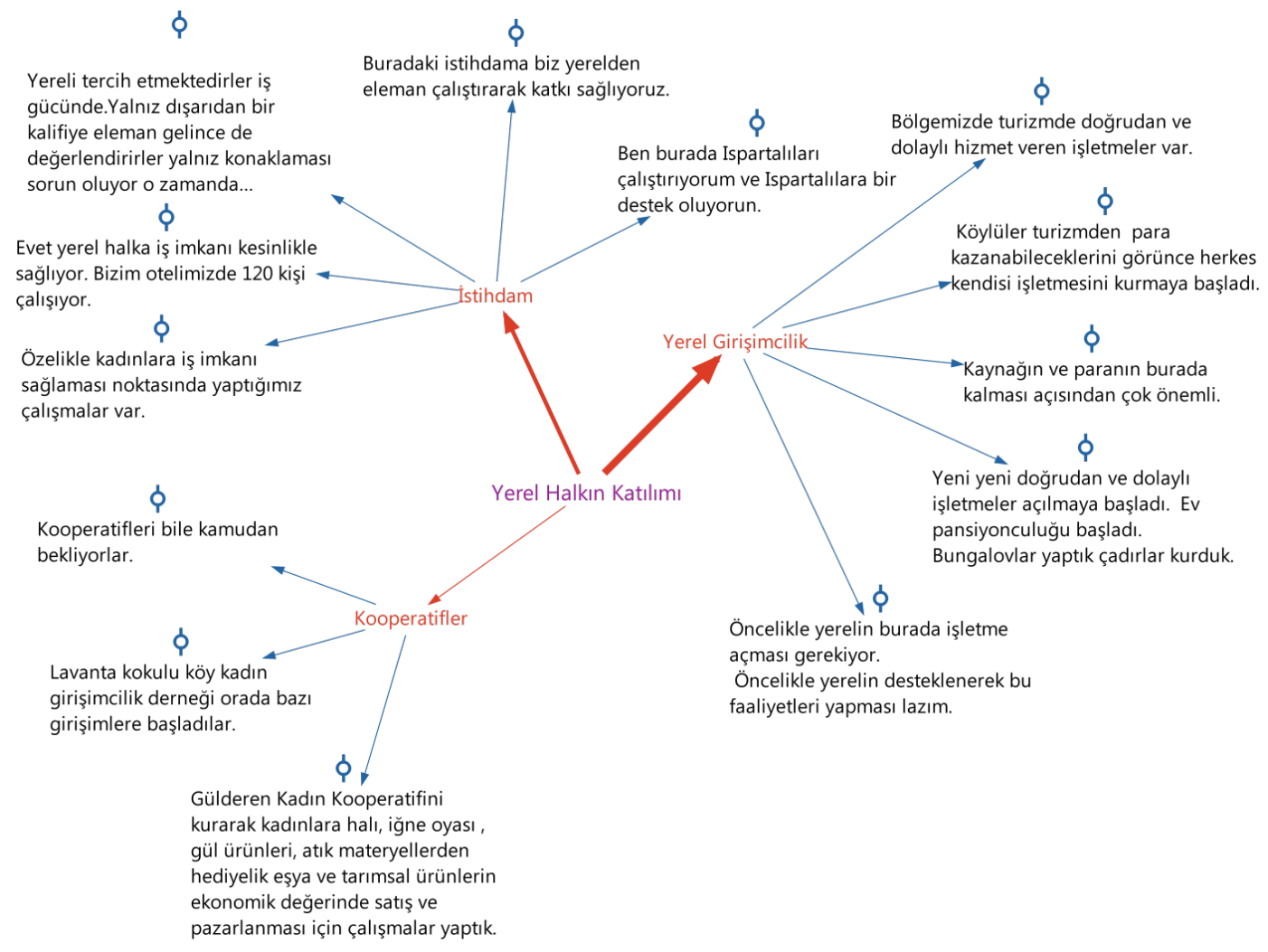

Şekil 2. Yerel Halkın Toplum Temelli Turizme Bakışı

Burdur ve Isparta yöresinde yapılan çeşitli toplantılara ve tanıtım çalışmalarına yerel halkın katılımı ve paydaşların bir araya gelme konusunda sıkıntılar olduğu tespit edilmiştir. Yapılan çalışmalarda bir bütünlük olmadığı, BAKA, İl Kültür ve Turizm Müdürlüğü, Belediyeler ve Kaymakamlıklar, bölgedeki oteller ve seyahat acentalarının çalışmalarında bir kopukluk olduğu, bir konuda birleşmenin zor olduğu ve bu konudaki sıkıntıların çözülmesi ve daha koordineli ve planlı gidilmesi gerektiği ifade edilmiştir.

Yerel girişimcilik alt kodunda bölgede turizmde doğrudan ve dolayı hizmet veren işletmelerin olduğu ve yerelin bu bölgede işletme açabilmesinin desteklenmesi gerektiği ifade edilmiştir. Ayrıca, son yıllarda bölgeye olan turizm talebindeki artışlarla yeni yeni işletmeler açıldığı ifade edilmiştir. Turizm gelirlerinin bu bölgede kalması açısından yerel girişimciliğin öneminden bahsedilmiştir. Kooperatifler alt kodunda, bölgede özellikle Kuyucak Köyü'nde kurulmuş olan Kadın Girişimcilik Kooperatifi bölgenin turizm gelişiminde öncü olduğu dile getirilmiştir. Kooperatiflerin yerel girişimcilik ile yeni işletmelerin açılması ve yerele istihdam sağlamada katkıları olduğu tespit edilmiştir. 
"Bölgede turizmin gelişmesi ile birlikte ekonomik, sosyo-kültürel ve çevresel etkiler oluşmuş mudur?" sorusuna bölgede turizm faaliyetleri ile ekonomik anlamda olumlu etkilerin ortaya çıtığı ifade edilmiştir. Sosyo-kültürel anlamda ise olumsuz etkilerin olmadığı katılımcıların buluştuğu noktadır. Çevresel etkiler açısından Yeşilova'da (Salda Gölü) turist talebinde ciddi bir artış yaşanması nedeniyle ve gölün etrafının birinci dereceden sit alanı olmasından dolayı kıyı kenar çizgisi kanuna göre alt yapı imkânlarını sağlama noktasında belediyenin yetersiz kaldığı ifade edilmiştir.

Bu konuda Kuyucak Köyü ise "Yalnız ayak izinizi bırakın başka bir şeyinizi bırakmayın" şeklindeki sloganı ile yoğun talebin çevreye olumsuz etkiler bırakmaması için yaptıkları çalışmalardan söz etmişlerdir.

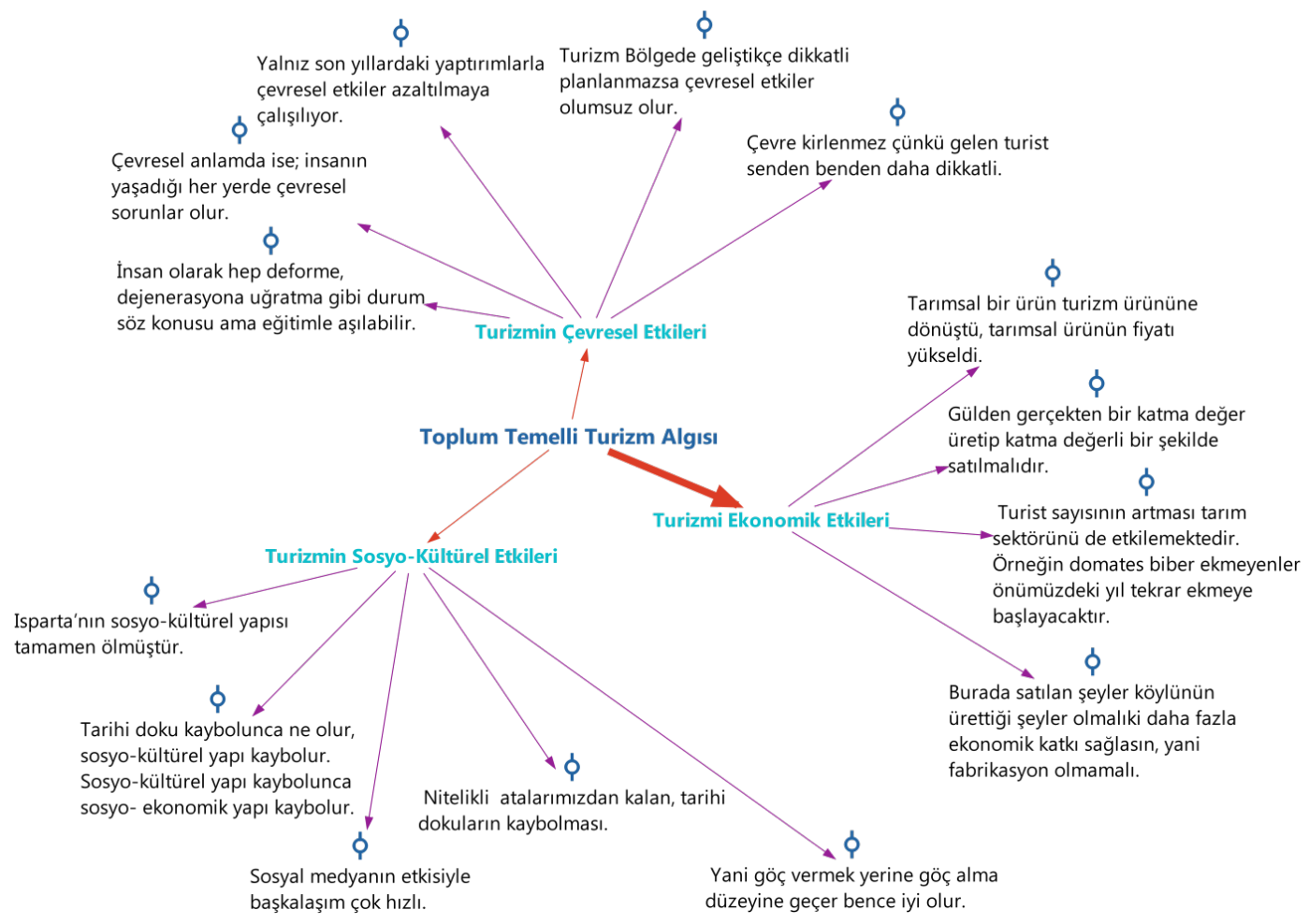

Şekil 3. Toplum Temelli Turizm Algısı

Şekil 3'te toplum temelli turizm algısı teması altında turizmin ekonomik, çevresel ve sosyokültürel etkileri incelendiğinde katılımcılar turizmin hem olumlu hem de olumsuz etkileri açısından değerlendirme yapmışlardır. Ekonomik etkileri açısından en çok dikkat çeken ve bir çok katılımcının dile getirdiği konu tarımsal bir ürünün turizm ürününe dönüştürülerek ekonomik değerinin artığını ifade etmişlerdir. Turist sayısının artması sadece turizm sektörünü değil aynı zamanda tarım sektörü ile birlikte birçok sektör ve alt sektörü de etkilediği dikkat çekmektedir. Sosyo-kültürel etkiler; sosyo-kütürel yapının sosyo-ekonomik yapı ile olan ilişkisi açısından değerlendiren katılımcılar eğer sosyoekonomik yapıda iyileşmeler olursa sosyo-kültürel yapının da bundan olumlu etkileneceği, bölgenin göç vermek yerine göç alabilecek bir duruma gelebilmesine karşın sosyal medyanın etkisi ile başkalaşımın çok hızlı olduğu ifade edilmiştir. Çevresel etkiler açısından; turizmin çevresel olarak hem olumsuz etkilerin ve hem de olumlu etkilerinin olduğunu ifade eden katılımcılar vardır. İnsanların olduğu yerde çevresel sorunlar 
çıkabileceğini ve bölgede turizm geliştikçe dikkatli planlama yapılmazsa çevresel sorunların doğabileceğini ifade eden katılımcılar olmakla birlikte çevrenin kirletilmeyeceğini, çünkü gelen turistlerin çevre konusunda daha duyarlı olduklarını ifade etmişlerdir. Aynı zamanda yapılan çalışmalarla gelen turistlere yönelik çevreye karşı duyarlılık konusunda çeşitli çalışmalar yapılmıştır.

Bugün Kuyucak ömrü hayatında hiç görmediği tarımdan hiç alamadığı kadar gelir elde ediyor lavantadan ve gün be gün yeni tesisler, yeni yerler, yeni bahçelerde kuleler inşa ediyorlar. Bunun sebebi ekonomik kazançtan kaynaklanıyor. Lavantayı çuval çuval satıyordu para kazanamıyordu. Şuan ise bir demek lavanta bir çuval lavantaya eşdeğer hale geldi. Bunlar önemli şeylerdi bunun farkına vardi. Benim lavantam tarımsal ürün değil turizm ürünüdür diyerek adın koydu...(K 10)

"Toplum temelli turizm hakkında ne düşünüyorsunuz?" sorusuna katılımclların büyük çoğunluğu bu kavramı duymadıklarını ifade etmişlerdir. Bazı katılımcılar fikirler yürütmüşlerdir. Ama biraz kavram hakkında bilgi verildikten sonra katılımcılardan açıklamalar gelmiştir.

Bana göre; kırsal turizmden bahsediyorsak toplum temelli turizm eşittir kırsal turizmdir. Mesela Antalya'daki beş yıldızlı otellerdeki turizm faaliyetlerini buna örnek veremeyiz. Toplum bunun sadece çalışan, işgören kısmında kalır. Isparta ve Burdur da yapmaya çalıştı̆̆ımız turizm faaliyetlerinde toplum; tarlada çiftçi, çalışan, iş yeri sahibi, ev pansiyoncusu, bölgeye yatırımı yapan kişi dolayısıyla her alanda yereli görmekteyiz. Aslında bizim burada yapmaya çalıştığımız toplum temelli turizm ile eş değer bir şey. Yöre insanın daha bilinçli, eğitimlerle evrilerek buraya kanalize edilmesi gerekiyor... (K 09)

Toplum temelli turizm ile ilgili bazı bölgelerimizde biz bu işi başardık, örneğin Güneykent'teki bayanlar, atıl eşyalardan oyuncak yaparak bunu başardı. Lavanta Kokulu Köy Kadın Girişimcilik Derneği orada bazı girişimlere başladılar. BAKA, Kırsak kalkınmayı destekleme birimi ve Kosgep gibi ajansların vermiş olduğ $u$ destekler var...(K 15).

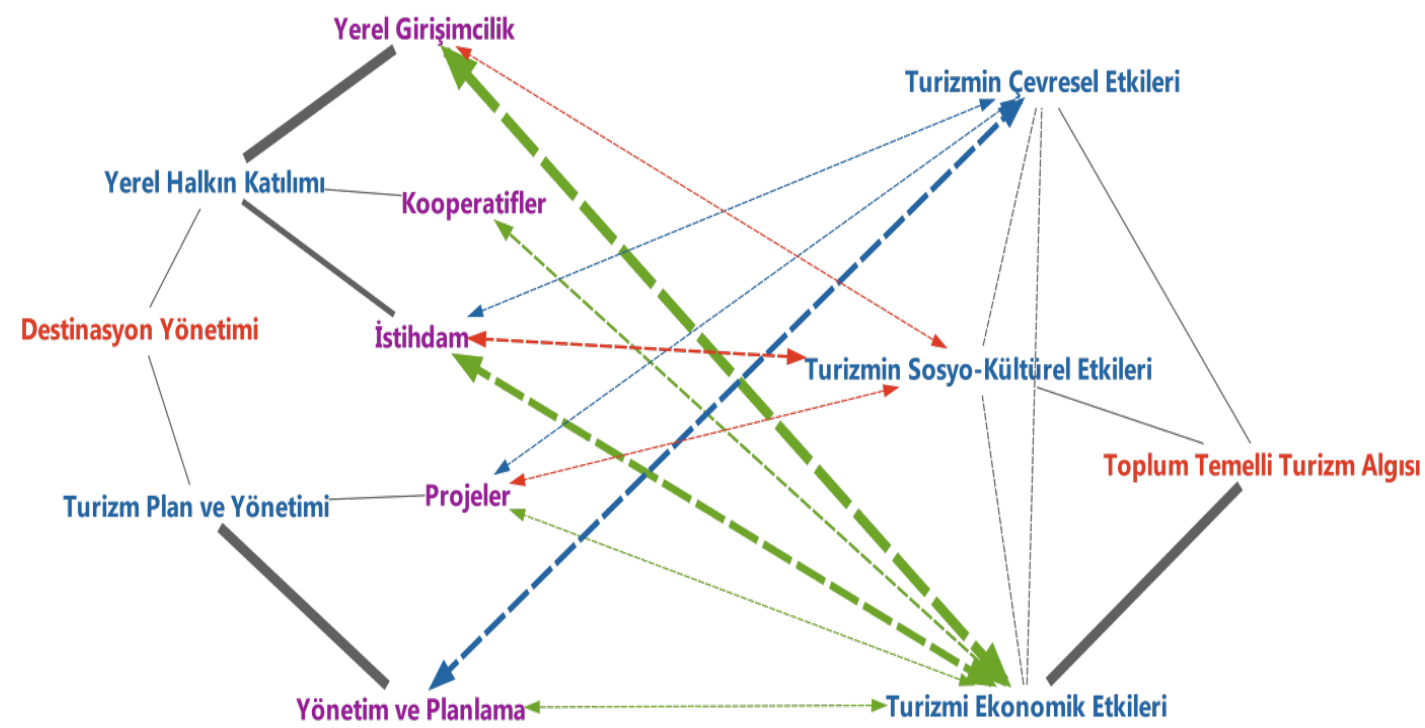

Şekil 4. Toplum Temelli Turizm ve Destinasyon Yönetimi Arasındaki İlişkiler 
Şekil 4'te toplum temelli turizm algıları teması altında ekonomik, sosyo-kültürel ve çevresel etkiler alt kodları çıkarılmıştır. Destinasyon yönetimi teması alında yerel halkın katılımı; projeler, yönetim ve planlama alt kodları oluşturulmuştur. Aynı tema altında turizm plan ve yönetimi başlığı altında yerel girişimcilik, kooperatifler ve istihdam alt kodları oluşturulmuştur. Daha sonra toplum temelli turizm algısı ve destinasyon yönetimi temaları oluşturulan Kod-Birlikte-Oluşma Modeli ile kodlar arasındaki ilişki haritası çıkarılmıştır. Alt kodlar arasındaki ilişkiye bakılacak olursa en güçlü ilişki turizmin ekonomik etkileri ve yerel girişimcilik arasındadır. Ayrıca turizmin ekonomik etkileri ile istihdam alt kodları arasında da güçlü bir ilişki olduğu görülmüştür. Turizmin sosyokültürel etkileri ile istihdam alt kodları arasında güçlü bir ilişki ve turizmin Çevresel etkileri ile Yönetim ve Planlama alt boyutları arasında güçlü bir ilişki olduğu görülmektedir.

Sonuç olarak turizm destinasyonlarında gerçekleştirilen turizm faaliyetlerin toplumun dezavantajlı kesimlerinin (kadınlar, gençler vb.) ekonomik, sosyal ve politik açıdan güçlenmesine katkıda bulunmaktadır (Giampiccoli ve Kalis, 2012:175). Ayrıca, toplum temelli turizmde elde edilen faydanın yerelde kalması bölgeden göçün azalmasına, yeni iş imkanlarının ortaya çıkmasına, sosyo-ekonomik sorunların azalmasına katkıda bulunmaktadır (Abdulrazzag vd., 2011). Çalışmada turizm ekonomik etkileri ile istihdam ve yerel girişimcilik arasındaki güçlü ilişki önceki çalışmaları destekler şekildedir. Benzer şekilde (Choi ve Sırakaya, 2006) çalışmasında çevrenin korunması ile yerel toplumun ihtiyaçlarının karşılanmasında sürdürülebilir bir çözüm yolu olarak toplum temelli turizm uygulamaları doğal çevre ve kültürü korumayı, toplumun yaşam kalitesinin arttırılmasının gerekliliğini vurgulamışlardır. Çalışmada turizmin çevresel etkilerini azaltma konusunda gerçekleştirilen turizm plan ve yönetim çalışmaları ile sürdürülebilir bir destinasyon yönetiminin gerekliliği vurgulanmıştır.

\section{SONUÇ ve ÖNERİLER}

2007 yılında yapılan Türkiye Turizm Stratejisi 2023 Eylem Planında; Tematik bölgelerden biri olarak Göller Bölgesi eko-turizmi gelişim bölgesi olarak belirlenmiştir. Bölge içinde yer alan göller odaklı "Turizm Merkezi" ilan edilebilecek alanların belirlenmesi, fiziki planların tamamlanmasından sonra turizm yatırımcılarına tahsisinin stratejik plan kapsaminda gerçekleştirileceği kararı alınmıştır (www.ktb.gov.tr).

Merkezi turizm planlamaları ile destinasyonlar yukarıdan aşağıya planlama çalışmaları yapılmaktadır. Bu merkezi planlama çalışmalarının, destinasyonların özellikleri ve bölgede yaşayan yerel halkın görüşleri ve turizme bakış açıları dikkate alınmadan yapılması destinasyonda sürdürülebilir turizm gelişimi açısından olumsuz sonuçlar doğurabilmektedir. Ev sahibi toplumun bölgedeki turizm plan ve yönetimine katılması turizm faaliyetlerinin içselleştirmesi ve yerel halkın bölgelerine sahip çıkmaları açısından çok önemlidir. Çalışmada görüşme sonuçlarına göre Isparta ve Burdur yöresinde destinasyon yönetimi ve toplum temelli turizm konularında dikkat çeken birtakım sonuçlara ulaşılmıştır.

Kuyucak Köyü; Isparta'nın Keçiborlu ilçesine bağlı, 84 haneden oluşan lavanta üretimde Türkiye'deki en önemli üretici konumunda olan köydür. Kuyucak Köyü'ne ilk kez 1975 yılında lavanta fidanları getirilmiştir. 30 aileye 15 kök dağıtılarak ev ve gül bahçelerinin etrafına görsellik oluşturması için hobi amaçlı lavanta üretimi başlamıştır. 1990'lı yıllardan sonra ise lavanta üretimi ticari bir boyut kazanmıştır (www. isparta.ktb.gov.tr). Kültür ve Turizm bakanlığı, Birleşmiş Milletler Kalkınma Programı ve Anadolu Efes ortaklığında 
yürütülen "Gelecek Turizmde" destek fonuna Lavanta Kokulu Köy Projesi ile 2015 yılında Keçiborlu Yardımlaşma, Dayanışma ve Eğitim Derneği, Keçiborlu Kaymakamlığı Köylere Hizmet Götürme Birliği ve Kuyucak Muhtarlığı ortaklığında Gelecek Turizmde destek fonuna başvurmuşlar ve projeleri kabul edilmiştir. Proje kapsamında reklam ve tanıtım çalışmalarına ağırlık verilerek turizm talebini artırmaya yönelik çalışmalar yapılmıştır. Ayrıca proje kapsamında bir kadın kooperatifi kurulmuş ve girişimcilik faaliyetleri başlamıştır. Şuan gelinen noktada hem köyde hem de Isparta merkezde turizm yatırımları artmıştır. Bu konuya en güzel örnek (K 01); Bölgede turizmden sadece Kuyucak değil, örneğin; taksiciler para kazanmaya başladı, uçak seferleri değiş̧ti, Isparta'da şuan 2 tane daha otel açıldr. Yani Hilton ve Ramada yeni açıldı bu yılin oteli bunlar. Isparta lavanta ile tanındiktan sonra bu kadar turist potansiyeli olduktan sonra bu kararlar verildi ve o işletmeler açıldr. Ama tanıtım yapılması lazım. Biz Lavanta Kokulu Köy olduysak bu işte sosyal medyanın etkisi çok fazladır. Bir bölgeye olan turist talebinin artması sadece turizm sektörünü değil birçok sektörü doğrudan ve dolaylı olarak etkilemektedir. Bu durumu burada net bir şekilde görülebilmektedir.

Bölgedeki turizm faaliyetlerinin planlaması ve yönetiminde o yörenin doğal kaynaklarına ve çevresel değerlerine zarar vermeden yapılması gerekmektedir. Bölgede yapılacak yatırımlarda yerelin desteklenmesi ve yapılacak olan çalışmalarda köy dokusuna zarar vermeden küçük ölçekli, çevreci ve betonarmeden ziyade daha çevreci malzemelerden yapılacak olan yapılara öncelik verilmesi gerekmektedir. Böylece Lavanta Kokulu Köy, örnek bir proje olarak başka alanlara ve destinasyonlara da ilham verebilir.

Yeşilova (Salda Gölii): Burdur'un Yeşilova ilçesi sınırları içinde yer alan Salda Gölü doğa harikası olması ve gölün ender toprak yapısı ve Göl'ün etrafının sit alanı olması özellikleri açısından önemli bir turizm bölgesidir. Beyaz kumları ve gölün masmavi rengi ile Türkiye'nin Maldivleri olarak nitelendirilen Salda Gölü görülmeye değer yerler arasında sayılabilir. Ulaşımın zor ve karayolları güzergahında yer almaması, bugüne kadar saklı bir cennet olarak ve doğal yapısının bozulmadan kalmasını sağlamıştır. Araştırmaya katılan katılımcılar, son bir kaç yılda yapılan tanıtım çalışmalarının artık meyvesini vermeye başladığını ve gelen turist sayısının arttığını ifade etmişlerdir. Ayrıca katılımcılar bölgeye gelen turistlerin ihtiyaçlarını karşılamakta zorlandıklarını ve bu yüzden tanıtımlara ara verdiklerini belirtmişlerdir. Yerel halk, gelen turist sayındaki artış ile birlikte göl ve çevresinin kirleneceği, gölün yapısının değişebileceği endişesi taşımaktadır. Görüşmeler ve gözlem sonuçlarına göre Göl ve civarında alt yapı çalışmalarının tamamlanması gerekmektedir. Ayrıca yerel halk geri plana itilme korkusu ve kalabalık gibi konularda da sıkıntılarını dile getirmişlerdir. Bu sebeple, bölgede yapılacak plan, proje ve yatırımlarda yerelin görüşlerinin dikkate alınması, göl ve çevresinin korunması için yapılacak olan yatırımlarda sürdürülebilirlik ilkelerinin dikkate alınması özellikle de koruyarak kullanma ilkesi ile hareket edilmesi son derece önemlidir. Ayrıca, bölgeye yapılacak yatırımlarda toplum temelli turizmin ilkelerinden olan yerel katılım, küçük ölçekli işletmelerle yerelin desteklenmesi, ekonomik kazancın yerelde kalması sağlanmalıdır.

Güneykent: Isparta' ya bağlı olan kasabanın bir turizm merkezi olarak gelişebilmesi amacıyla gül turizmi konusunda çalışmalar yapılmıştır. Bölgede tarımsal bir ürün olarak değerlendirilen gülün bir turizm ürününe dönüştürülmesi, değerinin arttırılması ve farkındalık oluşturması amaçlanmıştır. Bu amaç doğrultusunda; Gülderen Kadın Kooperatifi, Gülhaneler, Gül müzesi, Gülevi projesi ile atık (geri dönüşüm) materyaller kullanarak yaptıkları güle dair hediyelik eşya ürettikleri bir atölye ve hali, iğne oyası ve halı tasarımları gibi faaliyetler için eğitim programları gibi çalışmalar yürütülmüştür. Güneykent belediyesinin yaptığı çalışmalarla, kadınlara istihdam sağlanmış ve yerel 
girişimciliği desteklemesi açısından son derece önemli çalı̧̧malar yapılmıştır. Yapılan çalışmalar toplum temelli turizm uygulamaları ile benzerlikler göstermektedir. Bölgede bu tür çalışmaların devam etmesi için gelen turist sayısının artması ve yerelin turizm sektöründen de gelir elde etmesi turizmin içselleştirilmesinde ve desteklenmesinde son derece önemlidir.

Katılımcının dile getirdiği en önemli konulardan birisi de Burdur ve Isparta yöresi ile ilgili yapılan tanıtım çalışmalarının yetersiz olduğudur. Bölgeye yönelik tanıtım çalışmalarına ağırlık verilerek bölgeye olan turist talebinin arttırılması konusunda çeşitli çalışmalar yapılmaktadır. Bazı bölgelerde tanıtımda sosyal medyanın kullanılması ile birlikte gelen turist sayısında ciddi artışlar olduğu tespit edilmiştir. Sosyal medya özellikle Salda Gölü, Kuyucak Köyü gibi yerlerde bölgeye olan turizm talebini ciddi oranda arttırmıştır. Yetkililer bu durumu tahmin edemediklerini dile getirmişlerdir. Bu sebeple özellikle turizme kazandırılacak yerlerde sosyal medyaya ağırlık verilmesinin ve hatta halka sosyal medya konusunda eğitimler verilmesinin olumlu sonuçlar doğurabileceği tespit edilmiştir. Bu konuda (K 10); "sosyal medya kullanımı konusunda sınıfta kaldıklarını" ifade etmiştir.

Toplum temelli turizm ile ilgili yapılan çalışmalar incelendiğinde; Karacaoğlu vd. (2016:118) yaptıkları çalışma sonucunda Misi köyünde toplum temelli turizm projesinin gelir arttırma ve istihdam sağlamaya olan katkılarına dikkat çekmektedir. Özellikle kadın istihdamının arttırılması, kadının emeğinin karşılı̆̆ını bulması ve kadının ekonomik süreçlere dahil edilerek gelir elde etmesi, teşvik edilen bir gelişme olarak belirtilmiştir. Kuyucak Köyü'nde Yapılan Lavanta Kokulu Köy projesinde de benzer sonuçlar çıkmıştır. Ayrıca; araç trafiği, park yeri sorunları, kalabalık, turizmin gelişiminin yerel mal ve hizmetler üzerinde oluşturduğu fiyat artışı gibi konularla ilgili rahatsızlıklar Kuyucak Köyü'nde ve Yeşilova'da (Salda Gölü) da katılımcılar tarafından vurgulanmıştır. Toplum temelli turizm projeleri ile bölgede yapılan tanıtım çalışmaları, alt yapı ve üst yapı yatırımlarının destinasyon yaşam kalitesini geliştirdiğine yönelik benzer tespitler çeşitli çalışmalarda da vardır (Choi ve Sırakaya, 2006; López-Guzmán vd., 2011; Giampiccoli ve Kalis, 2012; Karacaoğlu vd., 2016). Çalışmada bölgede yapılacak yatırımlarda yerel halka öncelik verilmesi gerektiği katılımcılar tarafından çoğunlukla ifade edilmiştir. Yalnız bazı katılımcılar bölgenin turizme açılmasından sonra ilk yatırımların dışarıdan gelmesinin müşteri memnuniyeti, hizmet kalitesi gibi konularda yerele öncülük etmesi için daha önemli olduğunu vurgulamışlardır. Bu durum toplum temelli turizmin ilkelerine ters düşmektedir. Toplum temelli turizmde yerele öncelik verilmesi; yerel kalkınma, istihdam ve girişimcilik faaliyetleri açısından oldukça önemlidir. Ayrıca gerçekleştirilen planlama ve yönetim çalışmalarında destinasyon yaşam döngüsü ve destinasyon taşıma kapasitesi konularına da dikkat edilmelidir.

\section{KAYNAKÇA}

Abdul Razzaq, A. R., Hadi, M. Y., Mustafa, M. Z., Amran, H., Khalifah, Z. and Mohamad, N. H. (2011). Local Community Participation in Homestay Program Development in Malaysia, Journal of Modern Accounting and Auditing, 7 (12): 1418-1429.

Atay, L. (2003). Turistik Destinasyon Pazarlaması ve Bir Alan Uygulaması, Yayınlanmamış Doktora Tezi, Dokuz Eylül Üniversitesi, İzmir.

Boonratana, R. (2010). Community-Based Tourism in Thailand: The Need and Justification for an Operational Definition, Kasetsart Journal: Social Sciences, 31(2): 280-289. 
Buhalis, D. (2000). Marketing the Competitive Destination of the Future, Tourism Management, 21, 1: 97-116.

Cabael, T. G. (2011). Destinasyon Yönetim Organizasyonu Üzerine Bir Model Önerisi, Yayınlanmamış Yüksek Lisans Tezi, Muğla Üniversitesi, Muğla.

Choi, H. C. and Sirakaya, E. (2006). Sustainability Indicators for Managing Community Tourism, Tourism Management, 27(6): 1274-1289.

Daymon C. and Holloway I. (2005). Qualitative Research Methods in Public Relations and Marketing Communications, Routledge Taylor and Francis, New York.

David, L. and Tözser, A. (2009). Destination Management: Necessity and Tasks of Tourism Destination Management in Hungary, 4th Aspects and Visions of Applied Economics and Informatics Conference, 26 - 27 Mai, Hungary-Debrecen: 81-84.

Demers, T. (2011). Determinants of Successful Community-Based Tourism in Botswana, Unpublished Master's Thesis, The University of Guelph, Canada.

Dunn, S. (2007). Toward Empowerment: Women and Community-Based Tourism in Thailand, Unpublished Master's Thesis, University of Oregon, USA.

Eagles, P.F.J., McCool, S. F. and Haynes, C.D.A. (2002). Sustainable Tourism in Protected Areas: Guidelines for Planning and Management, IUCN Gland, Switzerland and Cambridge, UK.

Giampiccoli, A. and Kalis, J. H. (2012). Community-Based Tourism and Local Culture: The Case of the amaMpondo", Pasos: Revista de Turismo y Patrimonio Cultural, 10(1): 173-188.

Goodwin, H. and Santilli, R. (2009). Community-based Tourism: A Success, ICRT Occasional Paper, 11(1): 1-37.

Güripek, E. (2013). Turizm Destinasyonlarının Rekabet Gücünün Artırlmasında Stratejik Destinasyon Yönetimi: Çeşme Alaçatı Destinasyonu Üzerine Bir Uygulama, Yayınlanmamış Doktora Tezi, Dokuz Eylül Üniversitesi, İzmir.

Halmi, L. and Severović, K., (2016). Strategic Approach to Tourism Destination Management, The Małopolska School of Economics in Tarnów Research Papers Collection, 32(4): $77-86$.

Harris, R. and Vogel, D. (2007). E-Commerce for Community-Based Tourism in Developing Countries, Harris Roger Associates, Hong Kong: Star House Konwlon.

Hiwasaki, L. (2006). Community-based Tourism: A Pathway to Sustainability for Japan's Protected Areas, Society \& Natural Resources, 19(8): 675-692.

https://isparta.ktb.gov.tr/TR-163065/lavanta-kokulu-koy.html [Erişim Tarihi: 10.07.2019].

https://www.ktb.gov.tr/Eklenti/906,ttstratejisi2023pdf.pdf?0 [Erişim Tarihi: 24.04.2018].

Johnson, P.A. (2010). Realizing Rural Community Based Tourism Development: Prospects for Social-Economy Enterprises, Journal of Rural and Community Development, 5(1/2):150162.

Jones, B. (2016). Community-Based Tourism: An Exploratory Study of Barbados, Unpublised Thesis Doctor of Philosophy, Walden University, College of Management and Technology.

Karacaoğlu, S., Yolal, M. ve Birdir, K. (2016). Toplum Temelli Turizm Projelerinde Katılım ve Paylaşım: Misi Köyü Örneği, Çă̆ Üniversitesi Sosyal Bilimler Dergisi, 13(2): 103-124. 
Karasar, N. (2015). Bilimsel Araştırma Yöntemi (28. Basım). Ankara: Nobel Akademik Yayıncilık.

Kibicho, W. (2008). Community-Based Tourism: A Factor-Cluster Segmentation Approach, Journal of Sustainable Tourism, 16(2): 211-231.

López-Guzmán, T., Sánchez-Cañizares, S., and Pavón, V. (2011). Community-Based Tourism in Developing Countries: A Case Study, Tourismos: An International Multidisciplinary Journal of Tourism, 6(1): 69-84.

Neuman, L. W. (2014). Social Research Methods: Qualitative and Quantitative Approaches (Seventh Ed.). Essex: Pearson Education Limited

Özdemir, M. A. ve Kervankıran, İ. (2011). Turizm Ve Turizmin Etkileri Konusunda Yerel Halkın Yaklaşımlarının Belirlenmesi: Afyonkarahisar Örneği, Marmara Cŏ̆rafya Dergisi, 24: $1-25$.

Öztürk, Y. (2013). Destinasyon Tanımı ve Özellikleri, (Ed. M. Yeşiltaş), Destinasyon Yönetimi, Eskişehir, Anadolu Üniversitesi Yayınları: 2-18.

Patton, M. Q. (2005). Qualitative Research. New York: John Wiley \& Sons, Ltd.

Pike, S. (2008). Destination Marketing: An Integrated Marketing Communication Approach, USA:Butterworth-Heinemann.

Pinel, D. P. (1998). A Community-Based Tourism Planning Process Model: Kyuquot Sound Area, B.C.,Unpublished Master's Thesis, The University of Guelph, Canada.

Pookaiyaudom, G. (2012). A Comparative Analysis of International and Domestic Tourists' Perceptions of Community-Based Tourism: The Case of Pai, Thailand, Unpublished Thesis Doctor of Philosophy, University of Central Lancashire

Presenza, A., Sheehan, L. and Ritchie J. R. B. (2005). Towards a Model of The Roles and Activities of Destination Management Organizations, Journal of Hospitality, Tourism and Leisure Science, 3(1): 1-16.

Rozemeijer, N. (2001). Community-Based Tourism in Botswana: The SNV Experience in Three Community-Tourism Projects, SNV Botswana: Gaborone.

Rubin, A. and Babbie, E. R. (2016). Empowerment Series: Research Methods for Social Work. Boston: Cengage Learning.

Suansri, P. (2003). Community Based Tourism Handbook, Bangkok: Responsible Ecological Social Tours Project (REST).

Şencan, H. (2005). Sosyal ve Davranışsal Ölçümlerde Güvenilirlik ve Geçerlilik, Seçkin Yayıncılık, Ankara.

Taşçı A. D., Semrad, K. J. and Yılmaz, S. S. (2013). Community Basted Tourism: Finding the Equilibrium in the COMCEC Context, COMCEC Coordination Office.

Tosun, C. and Jenkins, C. L. (1996). Regional Planning Approaches to Tourism Development: The Case of Turkey, Tourism Management,17 (7): 519-531.

Usta, Ö. (2008). Turizm, Genel ve Yapısal Yaklaşım, Detay Yayıncılık, Ankara.

Vajirakachorn, T., (2011). Determinants of Success for Community-Based Tourism: The Case of Floating Markets in Thailand, Unpublished Doctor of Philosophy, Submitted to the Office of Graduate Studies of Texas A\&M University. 
Yıldırım, A. ve Şimşek, H., (2016). Sosyal Bilimlerde Nitel Araştırma Yöntemleri, Seçkin Yayıncilık, Ankara.

Zapata, M. J., Hall, C. M., Lindo, P., and Vanderschaeghe, M. (2011). Can Communitybased Tourism Contribute to Development and Poverty Alleviation? Lessons from Nicaragua, Current Issues in Tourism, 14: 725-749. 